\title{
Effect of Corporate Governance on Islamic Banking: Evidence from Listed Firms of Pakistani Stock Exchange
}

\author{
Laila Javeed \\ PhD Scholar (Finance), School of Finance \\ Zhongnan University of Economics and Law, China \\ E-mail:lailajaveed@hotmail.com
}

Received: January 4, 2019

Accepted: January 22, 2019

Published: January 23, 2019

doi:10.5296/ijafr.v9i1.14260

URL: https://doi.org/10.5296/ijafr.v9i1.14260

\begin{abstract}
The Purpose of this study is to analyze the influence of corporate governance on firm performance (Islamic Banks) in Pakistan. The study presents a longitudinal assessment of the compliance and implications of the revised code on firm performance. This study uses data from listed firms of Pakistan Stock Exchange (PSE) for the years 2007-2016 to investigate the effect of corporate governance, indices the performance of Islamic Banks. The study uses panel data analysis and random effect model. We used board size, CEO duality, board independence, director ownership, and frequency of meeting as corporate governance indices, ROE, and ROA as performance of Islamic banks proxies. The results have intimation for regulatory authorities, shareholders and directors to take steps to improve the board competencies for better performance.
\end{abstract}

Keywords: Islamic banks, Corporate governance, Firm performance, Board of directors, Pakistan Stock Exchange

\section{Introduction}

Awareness about the concept of corporate governance was bringing about when the scandals of World com and Enron, however it cannot be anticipated that the concept of corporate governance is innovative. Its requirement was in full swing when the management and ownership of organization has been separated. An amount of huge profile failures in 2001 and onwards have carried a developed emphasis on good corporate governance, which has taken the matter to a widespread conversation. Before exploring other, the concept of 
corporate governance should be well defined. Several members (supervisory officer, management, stakeholders, and workers) are correlated with the corporate governance in describing the approach and performance of organizations Alam Choudhury and Nurul Alam (2013) .There is an extensive volume of literature presented on this topic that certifies the existence of numerous definitions of this topic. Consequently, the aspect of this issue has been objectively limited; nevertheless, comprehensive extending definitions are stated. Thus, to develop a reasonable understanding on the topic it would be wise to give a narrow as well as a wide-ranging definition of corporate governance.

Corporate governance involves the relation between management, board of directors, stockholders and investors of firms. It consists of instructions that be responsible for the approach to be followed through which the intentions for the corporation are fixed. By ensuing the directions fix by corporate governance mechanism, the objectives of the firm are accomplished and productivity is supervised. Hence, the basic features of good corporate governance comprise clear corporate structures, simple techniques and the obligation of executives and board of directors concerning stakeholders. Corporate governance talks about to the managements which comprise the rules and regulations and the business dealings which can direct the relationship among shareholders and managements Oman (2001).

Generally, in the perspective of conventional banking system the corporate governance has been much evaluated as compared to Islamic banking system. Mainly the governance structures of Islamic banking, even though it's growing development during the last few decades Achchuthan et al, (2013).Certainly, the dynamic element of any organizational development is corporate governance and it is a huge challenge to the system of Islamic finance because of its additional risk as compared to the conventional banking system. When Islamic banks proceeding into the risk-sharing approaches the investors would become exposed to several types of risks namely Mudaraba and Musharaka Chapra (2007).So, it has intensely stated that any Islamic organization to have a proper corporate governance structure to certify its growth and success. The purpose of conducting this study is to measure the effect of corporate governance on Islamic banking performance to provide empirical evidence regarding Pakistani banks listed in PSE Over a period of 2007 to 2016. The remaining paper has been structured as follows. Section II presents review of literature. Section III elucidates the study's data and methodology. Section IV presents Empirical and Regression results finally; Section V provides the conclusion of the Research.

\section{Literature Review}

Governance has taken from the Greek word "kybernan which mean to steer, guide or govern. Corporate governance defined, as the relationship of the firm to all its stakeholders and the society" Yasser etal.,(2011).Generally, Corporate governance (CG) defined, is a set of procedures, strategies and rules distressing the way an institute is directed, managed and controlled Sulaiman et al.,(2003) . According to Bandsuch et al.,(2008) corporate governance is a set of dignified principles and processes executed by the holders, managers and the administration of the business in its several actions along with its relations with shareholders. 


\section{MlMacrothink}

International Journal of Accounting and Financial Reporting

ISSN 2162-3082

2019, Vol. 9, No. 1

Corporate governance as the provision of effective boards, strong shareholder rights, and broad disclosures in handling a business Holder-Webb et al, (2008).

Several studies on corporate governance and the structure of ownership have disclosed and mainly, corporate failures with difficulties. Generally stemming from untimely performance of good governance values Doost and Fishman (2004). Currently, it has enticed a great contract of communal interest as its seeming impact for the financial condition of corporate societies and organizations, particularly when scandals of corporate governance have controlled business features in the earlier few years. Therefore, the attention of governments, organizations and researchers has turned to studying the effect of corporate governance and ownership structure on performance of firms.

Practically, many proxies of corporate governance and capital structure have been used in previous works. Some of the variables used consist of board structure aspects (for instance board size, board independence, role duality, board meetings, family members on the board, audit committee structure) and ownership structure patterns (e.g. ownership concentration, ownership identity such as managerial ownership, government ownership, foreign ownership, institutional ownership, block ownership and employees ownership). According to (Friend \& Lang, 1988) those investors, having great attention to the corporations, play a significant role to regulate the management to take intense interest in the benefit of concentration group. However, command of corporate governance also permits bondholders to direct the management for the improvement of their agreement. Currently, a large number of researches have reliance on the practice of corporate governance index (CGI) study the role of corporate governance in firm performance Clacher et al., (2008); Bebchuk et al., (2008).

The study of Jensen, (1986) analyze that how corporate governance directly or indirectly effects the capital structure and the performance of firm. It has specified that superior ownership attention have a positive effect on capital structure and the performance of the firms. Furthermore, lesser ownership attention, the relationship depends upon the strictness of managerial decision making which impose to bring change in the capital structure Yasser et al., (2011). Moreover, Williams (2000) and Hassan Che Haat et al., (2008) determined, in their specific studies, that practices of corporate governance and the firms value have positive associated. Further, research of companies in crisis states has also steadily open an apparent linkage between corporate decline and corporate governance inadequacy and ineffectiveness Muranda (2006). Therefore, good governance is a key tool in the firm valuation process as well as the mitigation of agency conflicts. Several variables may organize benchmarks by which corporate governance can be dignified in a business. Some of these mechanisms are concisely explain below:

\subsection{Board Size}

Board of directors is the highest structure of an organization that is responsible for managing the firm and its operation. It has dynamic role in strategic decisions regarding financial mix. The main role of a board of directors is to regulate the agency costs causing the separation of ownership and control Fama and French (1995). According to Elsayed, (2007) and Dalton et al., (1998) huge boards are valued for the variety of practices the participants bring to the 


\section{$\triangle$ Macrothink}

International Journal of Accounting and Financial Reporting

ISSN 2162-3082 2019, Vol. 9, No. 1

board decision making. To avoiding corporate failure they recommend that a bigger board is more operative Dallas (2001).

Conversely, the resource dependence theory infers that larger boards might increase corporate performance as they offer various pools of proficiency, awareness and views that could provide valuable principles that decrease inner agency conflicts. As stated by Eisenberg et al., (1998), Carline et al.,(2002), and according to Mak and Kusnadi (2005), board size and firm performance are negatively correlated. However, some studies found a positive link between board size and firm performance Ahmed Sheikh \& Wang (2012); Belkhir, (2009). Actually, a board have small size may be less burdened with repetitive problems and may offer greater firm performance. Aggarwal et al.,(2007) found no relationship between board size and firm performance.

\subsection{Board Independence}

To control inside mechanism for observing the behaviors of upper management the board of directors is the most effective Fama and French (1995) and Jensen (1986). Conversely, empirical evidence in the existence of external independent directors and firm performance is mixed. As said by Hermalin and Weisbach (1991); Bhagat and Black (2001) found that there is no relationship among board independence and four measures of firm valuation, directing a variety of other governance variables, together with structures of ownership, firm and board size and industry. And it is documented that non-executive directors in the board become less operative if they stay with the similar board for several years Yasser et al., (2011). The code of Corporate Governance has limited listed companies in Pakistan that executive Directors requirement not be more than $75 \%$ of entire board size; as well encourage the representation of lesser stockholders and independent directors.

\subsection{CEO Duality}

Various theoretic opinions has used either to support or to challenge CEO duality. Shleifer \& Vishny, (1989) claim that CEOs who also control the board chair position (duality) use indefensible board effect, allowing the forte of the board's governance. In reality, there is possibility to be a deficiency of individuality amongst administration and the board if the CEO is also the board chair. In contrast, the stewardship theory forces that a unity of command of a CEO leads to certain governance above attendants, therefore, encourages effective decision-making Donaldson and Davis (1991). More researchers as Brickley et al., (1997) propose that there is no ideal management structure as both duality and separation views have related prices and profits.

Though Donaldson \& Davis, (1991) found no considerable changes in many financial indicators between firms that experienced CEO duality and firms that did not. Rechner and Dalton (1991) stated that firms with CEO duality steadily overtake firms with a CEO non-duality structure. CEO duality has also been related to other signs of ineffective governance, for instance in the case of opposed takeovers Morck et al., (1988b) or in the case of the use of "poison pills" Mallette and Fowler (1992). 


\subsection{Director Ownership}

There are unimpressed matters of the collision of director ownership in the literature Demsetz and Lehn (1985); Shleifer and Vishny (1997). Anton, (2016) proposed that the structure of ownership does persuade performance of institutes and suggested that the parting of ownership and authority. Although contradict the intents of Barle and Means by in encounter that the ownership is determined endogenously and organizations take the elevation of balance ownership. While (Weisbach, 1988) suggest that continually standardize ownership is pricey, such as an effect, organizations involve lesser than most satisfactory structure of ownership, mainly lesser performance level. Core and Laarcker (2002) work to come together the two observations relate to Demsetz \& Lehn, (1985) and Morck et al., (1988a). They argue that the time of preliminary astringent, the organizations initiate with a most encouraging level of managerial tenure. Therefore, organizations deviate and do not infinitely regulate the best level to avoid the re-contracting cost. In other words, when firm make your mind up whether to regulate to re-attain the most favorable level of ownership structure, at that time the firms divergence the marginal benefit and its cost.

The other variables have integrated in the research to confine the influence of economic uniqueness of the firm that the earlier literature supports also for the factors of the performance of the firms. The study provide vital confirmation that the equity risk is linked with the operating risk and the financial risk features of the firm together with the earning variability Carter etal., (2000) operating leverage Minton \& Schrand, (1999); earning persistence and financial leverage and spread Arzac, (1996); Mandelker and Rhee (1984). I include the control variables are log of assets Ln (Asset). Financial risk proxy by dividend payout (DP) leverages (LEV). The control variables are involved in the pooled estimations for other corporate governance characteristics: Big 5 auditor that controls for the risk associated with lower auditor quality and frequency of meeting.

\subsection{Corporate Governance in Pakistan}

All states have their own set of rules and regulations as per their social, political and religious needs. Some precedes the form of laws, some as per guiding principle however some are social norms. As stated by Black et al., (2003), these guidelines are pre-defined in black and white to assure that all the entities follow the similar set of directions and principles to certify a level playing field for all and protecting the rights of all stakeholders. Several states have issued their own set of corporate governance codes or strategies from early 2000 or later. Normally these are in the form of obligatory values applicable to the companies listed on the stock exchanges of the respective countries succeeding continuance of shareholders' rights.

In Pakistan, corporate governance is not yet well developed, but in the last few decades, the government has taken various steps to make marginal improvements mainly in 1991, when opening the secondary market for foreign investors on an equivalent basis with the native financiers. A number of countries have developed their own nationally defined codes of conduct for operative corporate governance. In Pakistan, the SBP took the initiative for development of corporate governance code of conduct so that a complete guidance on corporate governance provided to the BOD and management of the financial institutions. The 
security Stock Exchange commission of Pakistan (SECP) recognized to grow an advanced and effective corporate part, and a capital market based on sound regulatory principles to encourage economic development. January 1, 1999 SECP has started its operations. In order to establish a system on March 28, 2002 whereby a corporation is directed and organized by its executives in respect with the best practices so as to maintain the interests of diversified stakeholders. The Corporate governance has based on globally recognized values and lay emphasis on openness, clearness, and responsibility in the matters of listed companies.

The ancient, leading and liquid exchange of Pakistan is the Karachi Stock Exchange (KSE) .In the year 2002" it has been stated as the "Best performing stock market of the world. On 31 December 2007, 654 companies were listed with the market capitalization of Rs. 4,329,909 billion (US \$ 70.177) having listed capital of Rs. 671.27 billion (US \$ 10.880 billion). (According to KSE website www.kse.com.pk) The three indices are maintaining by Karachi Stock Exchange, which are in place, that is, KSE 30, KSE 100 Index and KSE all share index. These said indices are market capitalization-based indices.

Furthermore, it involves executives to release their fiduciary tasks thoroughly in the more comforts of all stakeholders. In summary, thesis of the provisions included in CCG relevant to board size, outside directors, qualification of directors, CEO duality, functions of board of directors, and financial reporting framework etc., is to the improvement of accountability and effectiveness in addition to enhance the benefits of an extensive cluster of investors relatively capitalize on them.

\section{Methodology and Model}

The sample consist of the financial organizations (banking sector) listed on Pakistan Stock Exchange. All of these firms have better admittance to capital and additional resources indispensable not only for continued existence but as well for humanizing their value in respect of their performance. Data has been collected from these 16 organizations for a 10 years' time period, from 2007 to 2016.And assembling information has been just for the years after the fact than the firm was recorded in the stock exchange. Many of the firms did not have information on key explanatory variables of this study, and therefore plummet out. The data for this study show up from the diverse wellsprings of secondary information. The data comes from the PSE data deep archive and Central Bank of Pakistan annual balance sheet analysis.

The General form of the model as follows:

$$
\text { Performance }(\text { ROA, ROE })=\mathrm{f}(\mathrm{BA}, \mathrm{BI}, \mathrm{BS}, \mathrm{CD}, \mathrm{DO}, \mathrm{DP}, \mathrm{FM}, \mathrm{FS}, \mathrm{LV}, \mathrm{RE}, \mathrm{DIV})
$$

The Econometric form of model as follows:

$$
\begin{aligned}
\mathrm{ROA} & =\alpha_{0}+\alpha_{1} B A_{i t}+\alpha_{2} B I_{i t}+\alpha_{3} B S_{i t}+\alpha_{4} C D_{i t}+\alpha_{5} D O_{i t} \\
& +\alpha_{6} D P_{i t}+\alpha_{7} F M_{i t}+\alpha_{8} F S_{i t}+\alpha_{10} L V_{i t}+\alpha_{11} D I V_{i t}+\varepsilon \\
\mathrm{ROE} & =\alpha_{0}+\alpha_{1} \mathrm{BA}_{\mathrm{it}}+\alpha_{2} \mathrm{BI}_{\mathrm{it}}+\alpha_{3} \mathrm{BS}_{\mathrm{it}}+\alpha_{4} \mathrm{CD}_{\mathrm{it}}+\alpha_{5} \mathrm{DO}_{\mathrm{it}} \\
& +\alpha_{6} D P_{i t}+\alpha_{7} F M_{i t}+\alpha_{8} F S_{i t}+\alpha_{10} L V_{i t}+\alpha_{11} D I V_{i t}+\varepsilon
\end{aligned}
$$




\subsection{Empirical Results}

This specific section exhibits the empirical analysis and exploration carried out within the data, which has shown and displayed in chapter three. The particular analysis and exploration has based on research methodology revealed in chapter 3 also. To evaluate the corporate governance on the performance of firms, a sample was unperturbed consisting of the Islamic firms listed at Pakistan Stock exchange. The first two sections elaborate the descriptive statistics and the correlation matrix. The third section introduces and discusses the econometric model and explains how the model specified has estimated and evaluated. The fourth and last section presents an interpretation of the experimental results.

Table 1. Descriptive statistics

\begin{tabular}{lllll}
\hline Variables & Mean & Std.Dev & Max & Min \\
\hline BI & 0.5226 & 0.21883 & 0.85714 & 0 \\
\hline BS & 8.4687 & 2.4569 & 16 & 6 \\
\hline BA & 0.5625 & 0.4976 & 1 & 0 \\
\hline CD & 0.5 & 0.5015 & 1 & 0 \\
\hline FS & 21.9868 & 3.4027 & 31.4390 & 14.9446 \\
\hline LV & 0.9453 & 1.2176 & 8.2760 & 0.0014 \\
\hline DO & 4.9165 & 6.4324 & 28.05 & 0 \\
\hline FM & 6.6250 & 2.7852 & 8 & 4 \\
\hline DIV & 4.4331 & 10.0303 & 61 & 0 \\
\hline ROE & 18.3834 & 6.5838 & 42.0202 & 0.0700 \\
\hline ROA & 1.3919 & 0.8800 & 6.8637 & 0.0037
\end{tabular}

Table 2. Correlation matrix

\begin{tabular}{|c|c|c|c|c|c|c|c|c|c|c|c|}
\hline & BI & BS & $\mathrm{BA}$ & $\mathrm{CD}$ & FS & LV & DO & FM & DIV & ROE & ROA \\
\hline BI & 1 & & & & & & & & & & \\
\hline BS & 0.1267 & 1 & & & & & & & & & \\
\hline BA & 0.1536 & 0.3334 & 1 & & & & & & & & \\
\hline $\mathrm{CD}$ & -0.1486 & -0.1301 & -0.3780 & 1 & & & & & & & \\
\hline FS & -0.1181 & 0.1925 & -0.4886 & 0.1217 & 1 & & & & & & \\
\hline
\end{tabular}




\begin{tabular}{llllllllllllll}
\hline LV & 0.0675 & -0.1005 & -0.1314 & 0.0190 & -0.0488 & 1 & & & & \\
\hline DO & 0.0740 & 0.1886 & 0.1447 & 0.2658 & -0.1502 & -0.0170 & 1 & & & \\
\hline FM & -0.0737 & -0.0982 & 0.0397 & -0.1756 & -0.1756 & -0.0635 & 0.0730 & 1 & & \\
\hline DIV & 0.0062 & -0.1705 & 0.1611 & -0.1284 & -0.2766 & -0.1666 & -0.1838 & -0.0521 & 1 & & \\
\hline ROE & -0.0909 & 0.1564 & 0.0453 & -0.1765 & 0.1029 & -0.1344 & -0.2919 & -0.1756 & 0.0969 & 1 & \\
\hline ROA & -0.0936 & -0.0378 & -0.2743 & 0.3615 & -0.1181 & -0.0294 & 0.0630 & -0.1422 & -0.0503 & 0.0400 & 1 \\
\hline
\end{tabular}

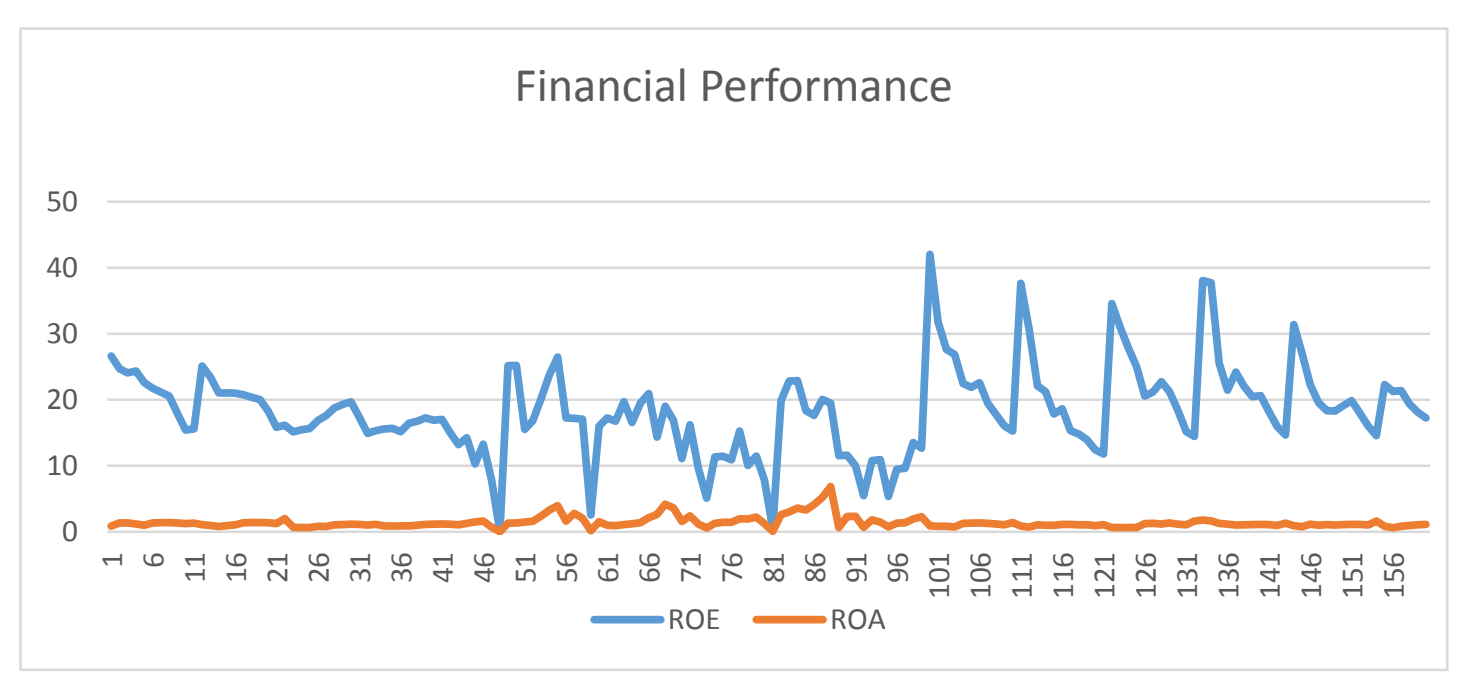

Figure 1. Financial performance

Table 3. Regression results

\begin{tabular}{lllll}
\hline Variables & Model 1 & \multicolumn{3}{l}{ Model2 } \\
\hline BI & Coefficient & Prob. & Coefficient & Prob. \\
\hline BS & -0.5288 & 0.156 & $-3.0970^{* *}$ & 0.005 \\
\hline BA & 0.0316 & 0.644 & $0.6274^{*}$ & 0.055 \\
\hline CD & $0.8577 * *$ & 0.009 & -1.7789 & 0.338 \\
\hline FS & 0.4090 & 0.557 & $-1.1609 *$ & 0.059 \\
\hline LV & -0.0314 & 0.430 & -0.13208 & 0.563 \\
\hline DO & $-0.0902 * *$ & 0.085 & -0.3611 & 0.384 \\
\hline FM & $-0.0281 * *$ & 0.020 & $-0.3109 * *$ & 0.009 \\
\hline DIV & -0.0451 & 0.612 & $0.3745^{* *}$ & 0.047 \\
\hline
\end{tabular}




\begin{tabular}{|c|c|c|c|c|}
\hline $\mathrm{C}$ & -1.2231 & 0.528 & 21.7949 & 0.290 \\
\hline $\mathrm{R} 2$ & 0.2091 & & 0.1451 & \\
\hline F-Statistics & 7.3012 & & 4.2709 & \\
\hline Prob.value & 0.0000 & & 0.0067 & \\
\hline
\end{tabular}

$*, * *, * * *$ represent the significance level at $10 \%, 5 \%$ and $1 \%$ respectively.

The above result show that the random effect model, in the first model the coefficient of determination is 0.2091 , which means that the $20 \%$ variation explained by the explanatory variable. The overall model is good because the probability value of the F-statistics is significant. The variable of big five editor is statistically significant which means that it is the good effect on the performance of the Islamic organizations. In the same time, the variable of director ownership is negative and significant which means that if more the percentage of the director ownership then it leads to the less performance of the organizations. In addition, there is no effect the frequency of the meeting on the performance of the Islamic organizations. In the second model, the coefficient of determination is weak as compared to the first model. In this model, $14 \%$ variation explained by the independent variable. Also in this model, the director ownership is negative and significant.

\section{Conclusion}

This paper scrutinize whether the corporate governance deviation in the BI, BS, DO and CD along with the companies juncture of enlargement, coalesce to persuade the performance of the Islamic organizations. This study covers the period of 2007-2016. The authoritarian rules and recommendations on the characteristics of board are based on the hypothesis that one size fits all. Therefore, this statement is confront by available literature (Linck, Netter, \& Yang, 2008), and this study append more evidence that is incompatible amid this one size fit all loom to the characteristics of board in governance. The regulatory guiding principle also presume that the lack of independence in board, the ownership of director, CD and consequently potentially risky for shareholders. This study also portray on the agency scaffold and differences in the enlargement of the firms to develop and substantiation that confront these statement.

Using two regression models, the overall results exhibit the role of corporate governance aspects in firm performance (Islamic banks) have somehow amended. While the outcomes showed a marginal significant negative relationship between board independence and director ownership with market performance, the results in the years 2007-2016 exposed that all corporate governance attributes, with the exemption of independent chairperson, have a significant negative relationship with one of the performance measures. The existence of an independent chairperson is the only outstanding corporate governance element to have shown a reliable association with all performance measures in data sets, with its significance viewing an enhancement following the policy changes. Hence, the results recommend the incidence of an independent chairperson in the corporate governance have an encouraging 
influence on firm performance, even in the worst scenarios of financial crisis. As a result, organizations might want to consider assigning an independent leader at the upper level. The supervisors in Pakistan and in other similar emerging economies might want to deliberate to reassure listed companies to have an independent chairperson at the highest level. In terms of director ownership structure and designs, the outcomes designate that ownership had a significant negative impact on firm performance.

This study endow with numerous new imminent to the corporate governance literature. The results confirm earlier confirmation with the intention of the performance amid the firms' governance configuration. For example, the structure on crams of characteristics of board by Ashbagh-Skafe and La (2004) in U.S. surroundings. Faleye and Krishan (2010) cram the board of financial institutional. In fact, that we locate with the intention of the characteristics of board allied amid the performance of the Islamic organizations. Therefore, the study designates the decisive magnitude of the formation of highpoint management group for the valuable organization.

\section{References}

Achchuthan, S., Rajendran, K., \& Sivathaasan, N. (2013). Corporate governance practices and capital structure: A case in Sri Lanka.

Aggarwal, R., Erel, I., Stulz, R. M., \& Williamson, R. (2007). Do US Firms Have the Best Corporate Governance? A Cross-Country Examination of the Relation Between Corporate Governance and Shareholder Wealth. National Bureau of Economic Research.

Ahmed Sheikh, N., \& Wang, Z. (2012). Effects of corporate governance on capital structure: empirical evidence from Pakistan. Corporate Governance: The International Journal of Business in Society, 12(5), 629-641.

Alam Choudhury, M., \& Nurul Alam, M. (2013). Corporate governance in Islamic perspective. International Journal of Islamic and Middle Eastern Finance and Management, 6(3), 180-199.

Anton, F. X. (2016). Menuju Teori Stewardship Manajemen. Majalah Ilmiah Informatika, $1(2)$.

Arzac, E. R. (1996). Valuation of highly leveraged firms. Financial Analysts Journal, 52(4), 42-50.

Bandsuch, M., Pate, L., \& Thies, J. (2008). Rebuilding stakeholder trust in business: An examination of principle-centered leadership and organizational transparency in corporate governance. Business and Society Review, 113(1), 99-127.

Bebchuk, L., Cohen, A., \& Ferrell, A. (2008). What matters in corporate governance?. The Review of Financial Studies, 22(2), 783-827.

Belkhir, M. (2009). Board of directors' size and performance in the banking industry. International Journal of Managerial Finance, 5(2), 201-221. 


\section{MInstitute Macrothink $_{\text {Int }}$}

International Journal of Accounting and Financial Reporting ISSN 2162-3082

Bhagat, S., \& Black, B. (2001). The non-correlation between board independence and long-term firm performance. J. CorP. L., 27, 231.

Black, B. S., Jang, H., \& Kim, W. (2003). Does Corporate Governance Affect Firm Value?: Evidence From Korea. University of Chicago Law School, Law and Economics Workshop.

Brickley, J. A., Coles, J. L., \& Jarrell, G. (1997). Leadership structure: Separating the CEO and chairman of the board. Journal of Corporate Finance, 3(3), 189-220.

Carline, N. F., Linn, S. C., \& Yadav, P. K. (2002). The Influence of Managerial Ownership on the Real Gains in Corporate Mergers and Market Revaluation of Merger Partners: Empirical Evidence.

Carter, C. R., Kale, R., \& Grimm, C. M. (2000). Environmental purchasing and firm performance: an empirical investigation. Transportation Research Part E: Logistics and Transportation Review, 36(3), 219-228.

Chapra, M. U. (2007). 21 Challenges facing the Islamic financial industry. Handbook of Islamic Banking, 325.

Clacher, I., Doriye, E. J., \& Hillier, D. (2008). Does Corporate Governance Matter? New Evidence From the United Kingdom.

Dallas, L. (2001). Developments in US Boards of Directors and the Multiple Roles of Corporate Boards.

Dalton, D. R., Daily, C. M., Ellstrand, A. E., \& Johnson, J. L. (1998). Meta-analytic reviews of board composition, leadership structure, and financial performance. Strategic Management Journal, 19(3), 269-290.

Demsetz, H., \& Lehn, K. (1985). The structure of corporate ownership: Causes and consequences. Journal of Political Economy, 93(6), 1155-1177.

Donaldson, L., \& Davis, J. H. (1991). Stewardship theory or agency theory: CEO governance and shareholder returns. Australian Journal of Management, 16(1), 49-64.

Doost, R. K., \& Fishman, T. (2004). Beyond Arthur Andersen: searching for answers. Managerial Auditing Journal, 19(5), 623-639.

Eisenberg, T., Sundgren, S., \& Wells, M. T. (1998). Larger board size and decreasing firm value in small firms. Journal of Financial Economics, 48(1), 35-54.

Elsayed, K. (2007). Does CEO duality really affect corporate performance?. Corporate Governance: An International Review, 15(6), 1203-1214.

Fama, E. F., \& French, K. R. (1995). Size and book-to-market factors in earnings and returns. The Journal of Finance, 50(1), 131-155.

Friend, I., \& Lang, L. H. P. (1988). An empirical test of the impact of managerial self-interest on corporate capital structure. The Journal of Finance, 43(2), 271-281. 


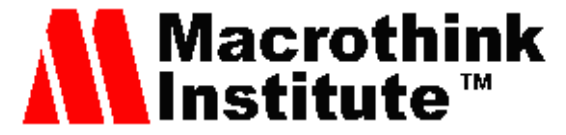

International Journal of Accounting and Financial Reporting

ISSN 2162-3082

2019, Vol. 9, No. 1

Hassan Che Haat, M., Abdul Rahman, R., \& Mahenthiran, S. (2008). Corporate governance, transparency and performance of Malaysian companies. Managerial Auditing Journal, 23(8), 744-778.

Hermalin, B. E., \& Weisbach, M. S. (1991). The effects of board composition and direct incentives on firm performance. Financial Management, 101-112.

Holder-Webb, L., Cohen, J., Nath, L., \& Wood, D. (2008). A survey of governance disclosures among US firms. Journal of Business Ethics, 83(3), 543-563.

Jensen, M. C. (1986). Agency costs of free cash flow, corporate finance, and takeovers. The American Economic Review, 76(2), 323-329.

Linck, J. S., Netter, J. M., \& Yang, T. (2008). The determinants of board structure. Journal of Financial Economics, 87(2), 308-328.

Mak, Y. T., \& Kusnadi, Y. (2005). Size really matters: Further evidence on the negative relationship between board size and firm value. Pacific-Basin Finance Journal, 13(3), 301-318.

Mallette, P., \& Fowler, K. L. (1992). Effects of board composition and stock ownership on the adoption of "poison pills." Academy of Management Journal, 35(5), 1010-1035.

Mandelker, G. N., \& Rhee, S. G. (1984). The impact of the degrees of operating and financial leverage on systematic risk of common stock. Journal of Financial and Quantitative Analysis, 19(1), 45-57.

Minton, B. A., \& Schrand, C. (1999). The impact of cash flow volatility on discretionary investment and the costs of debt and equity financing. Journal of Financial Economics, 54(3), 423-460.

Morck, R., Shleifer, A., \& Vishny, R. W. (1988a). Alternative mechanisms for corporate control. National Bureau of Economic Research Cambridge, Mass., USA.

Morck, R., Shleifer, A., \& Vishny, R. W. (1988b). Management ownership and market valuation: An empirical analysis. Journal of Financial Economics, 20, 293-315.

Muranda, Z. (2006). Financial distress and corporate governance in Zimbabwean banks. Corporate Governance: The International Journal of Business in Society, 6(5), 643-654.

Oman, C. P. (2001). Corporate Governance and National Development.

Rechner, P. L., \& Dalton, D. R. (1991). CEO duality and organizational performance: A longitudinal analysis. Strategic Management Journal, 12(2), 155-160.

Shleifer, A., \& Vishny, R. W. (1989). Management entrenchment: The case of manager-specific investments. Journal of Financial Economics, 25(1), 123-139.

Shleifer, A., \& Vishny, R. W. (1997). A survey of corporate governance. The Journal of Finance, 52(2), 737-783. 


\section{Macrothink}

International Journal of Accounting and Financial Reporting ISSN 2162-3082 2019, Vol. 9, No. 1

Sulaiman, M., Majid, N., \& Ariffin, N. (2011). Corporate governance of Islamic Financial Institutions in Malaysia.

Weisbach, M. S. (1988). Outside directors and CEO turnover. Journal of Financial Economics, 20, 431-460.

Williams, S. M. (2000). Relationship Between Board Structure and a Firm'S Intellectual Capital Performance in an Emerging Economy. University of Calgary.

Yasser, Q. R., Entebang, H., \& Mansor, S. A. (2011). Corporate governance and firm performance in Pakistan: The case of Karachi Stock Exchange (KSE)-30. Journal of Economics and International Finance, 3(8), 482-491.

\section{Copyright Disclaimer}

Copyright for this article is retained by the author(s), with first publication rights granted to the journal.

This is an open-access article distributed under the terms and conditions of the Creative Commons Attribution license (http://creativecommons.org/licenses/by/4.0/) 